\title{
ICE-SHEET FLOW PROPERTIES DERIVED FROM BORE-HOLE SHEAR MEASUREMENTS COMBINED WITH ICE-CORE STUDIES
}

\author{
By D. S. Russell-Head \\ (School of Earth Sciences, University of Melbourne, Parkville, Victoria 3052, Australia) \\ and W. F. BudD \\ (Antarctic Division, Department of Science, 568 St Kilda Road, Melbourne, Victoria 3004, \\ Australia)
}

Abstract. A $345 \mathrm{~m}$ deep bore hole in ice about $385 \mathrm{~m}$ thick, near the edge of Law Dome, Antarctica, was drilled in 1974 about $3 \mathrm{~km}$ up-stream from the site of a previous bore hole, nearly reaching the bed, obtained in 1969 . The core from this new bore hole has been studied comprehensively, particularly with regard to the ice-crystal orientation fabrics. Samples of the ice core were subjected to simple shear at temperatures and deviatoric stresses which match the in situ conditions of the ice sheet.

Similar studies of randomly-oriented laboratory-made polycrystalline ice were undertaken. Long-term tests, lasting for up to two years, were required to determine minimum strain-rates. The flow law for the anisotropic ice was thus determined as a function of that for the isotropic ice together with a measure of $c$-axis fabric strength perpendicular to the shear plane.

Core studies indicate that the upper part of the ice sheet has a polycrystalline structure appropriate to the surface longitudinal stress. Deeper in the core a strong concentration of near-vertical $c$-axes develops. Ice having very large crystals with multiple maxima fabrics was found in the lower quarter of the ice thickness.

Shear measurements in the bore hole indicate the existence of high strain-rates in the zone of vertical $c$-axes, and of lower shear-rates below that level. The low values of shear-rates in the basal region cannot be explained in terms of crystallographic changes alone, and therefore it is inferred that the shear stress decreases in this layer-a result which also provides a possible explanation for the development of the observed basal
crystal structure.

RÉsumÉ. Propriétés de l'écoulement des calottes glaciaires deduites des mesures de cisaillement dans des forages combinées avec l'étude des carottes de glace. Unn forage profond de $345 \mathrm{~m}$ dans une glace épaisse d'environ $385 \mathrm{~m}$ vers la limite du Law Dome en Antarctique a été creusé en 1974 à environ $3 \mathrm{~km}$ à l'amont de l'emplacement d'un précédent forage, atteignant presque le lit rocheux, réalisé en ig69. On a étudié à fond la carotte issue de ce nouveau forage en particulier sous l'angle de l'orientation des axes des cristaux de glace. Des échantillons de carottes de glace ont été soumises à des cisaillements simples à des températures et avec des déviateurs de contraintes qui reproduisent les conditions in situ de la calotte glaciaire.

On a entrepris des études semblables sur de la glace polycristalline à orientation quelconque fabriquée en laboratoire. Les essais à long terme s'étendant sur plus de deux ans, étaient nécessaires pour déterminer les vitesses de déformation minimum. La loi d'écoulement pour une glace anisotrope a alors été déterminée comme une fonction de celle s'appliquant à la glace isotrope associée à une mesure de l'abondance des cristaux à axes- $c$ perpendiculaires au plan de cisaillement.

Les études de carottes indiquent que la partie supérieure des calottes glaciaires ont une structure polycristalline adaptée aux efforts longitudinaux en surface. Plus profond dans la carotte une forte concentration d'axes- $c$ presque verticaux se manifeste. De la glace à très grands cristaux et de multiples maximums d'orientations d'axes a été trouvé dans le dernier quart de l'épaisseur de la glace.

Les mesures de cisaillement dans le forage sont l'indice de l'existence d'une forte vitesse de déformation dans la zone à axe- $c$ verticaux et d'un plus faible cisaillement sous ce niveau. Les faibles valeurs des vitesses de cisaillement dans la région du fond ne peuvent s'expliquer seulement par des changements cristallographiques et on en déduit donc que le cisaillement diminue à ce niveau - un résultat qui procure également une explication probable pour le développement de la structure cristalline observée à la base.

Zusammenfassung. Eigenschaften des Eisflusses, hergeleitet aus Schermessungen im Bohrloch, kombiniert mit Bohrkernuntersuchungen. Nahe dem Scheitel des Law Dome, Antarktis, wurde 1974 ein $345 \mathrm{~m}$ tiefes Bohrloch ins etwa $385 \mathrm{~m}$ dicke Eis niedergebracht, ca. $3 \mathrm{~km}$ stromaufwärts von der Stelle eines Bohrloches aus dem Jahr 1969 , das beinahe das Felsbett erreichte. Der Kern dieses neuen Bohrloches wurde eingehend untersucht, besonders im Hinblick auf das Gefüge der Kristallorientierung. Proben des Eiskernes wurden einfacher Scherung unterworfen, bei Temperaturen und Auslenkspannungen, die den in situ-Bedingungen des Eisschildes entsprachen.

Ähnliche Untersuchungen wurden an zufällig orientiertem, künstlichem polykristallinem Eis angestellt. Zur Bestimmung der minimalen Verformungsraten waren Langzeittests bis zu zwei Jahren Dauer erforderlich. Das Fliessgesetz für anisotropes Eis wurde so als Funktion dieses Gesetzes für isotropes Eis zusammen mit einem Mass für die Fertigkeit des $c$-Achsengefüges senkrecht zur Scherebene bestimmt. 
Kernstudien zeigen, dass der obere Teil des Eisschildes eine polykristalline struktur besitzt, die der Längsspannung an der Oberfläche entspricht. Tiefer unten entwickelt sich im Kern eine starke Konzentration beinaher vertikaler c-Achsen. Im untersten Viertel des Eiskerns wurde Eis von grosser Korngrösse und einem Gefüge mit mehreren Maximen gefunden.

Schermessungen im Bohrloch deuten auf das Vorhandensein hoher Verformungsraten in der Zone vertikaler $c$-Achsen und geringerer Scherraten unter diesem Niveau. Diese geringen Scherungswerte können nicht durch kristallographische Veränderungen allein erklärt werden; es wird daher angenommen, dass der Scherdruck in dieser Schicht abnimmt, - ein Ergebnis, das auch eine mögliche Erklärung für die Bildung der beobachteten Kristallstruktur am Untergrund liefert.

\section{Aims of the PROJEGT}

In large ice masses there is an interrelation between the deformational flow and the ice crystal structure (i.e. the structure of the ice polycrystalline aggregate specified by the patterns or fabrics of the crystal shapes, sizes, orientations, and lineations, etc.). A two-part study, as outlined by Budd (1972), has been undertaken in order to understand these phenomena.

The first part of the study is aimed at a determination of the manner in which the ice crystal structure develops in ice masses; this was outlined in a general way in Budd (1972). The general pattern described there has been further confirmed by subsequent work on Law Dome, Antarctica, to be described below, and on other locations (e.g. Barnes Ice Cap; Hooke (1973)), and also by laboratory experiments (e.g. Budd and Matsuda, 1974).

The second part is directed towards a determination of the flow law of anisotropic ice in a given stress configuration. This configuration is defined by the relative magnitudes of the principal stresses and their directions with respect to the directions of the anisotropic crystal structure. This topic has been examined in a general way by Lile (1978). The aim of the present project has been to determine the crystal structure of a real ice mass, and to determine the flow properties of the ice under typical in-situ conditions both by measurements of bore-hole deformation in the ice sheet and by measurements on the ice core in the laboratory.

\section{BACKGROUND AND LOGATION}

The site chosen for the field work was Law Dome, nine kilometres inland from the coasts, on a flow line from the Dome Summit to Cape Folger, for which a great deal of background and support data was already available. Surface elevation, ice thickness, snow accumulation rates, surface strain-rates, and velocities have been reported by Budd (r968), McLaren ( 1968 ), and Budd ([1970]). Core drilling commenced in 1969, and further programmes have been carried out in 1972, 1974, and 1977. The locations of the bore holes drilled up to I974 are presented along with the analysis of the temperature profiles by Budd and others (1976). Results of the ice-core oxygen-isotope ratios $\left({ }^{16} \mathrm{O} /{ }^{18} \mathrm{O}\right)$, measured from the cores and from samples taken over the surface of the ice cap, are presented, together with results of the ice-core gas content, by Budd and Morgan (1977).

From these earlier studies, the flow line from the Dome Summit to Cape Folger has been modelled in detail to calculate ice-particle paths, ages of the ice, temperature profiles, and flow-law-derived velocity profiles. The present regime has been assumed, for this work, to be steady state. The resultant particle paths and ages together with the bore-hole locations, including the two new ones of 1977 , are shown in Figure 1 . The results of the isotope measurements from the Cape Folger core, in comparison with the surface isotope ratios and the particle paths, suggest that the Law Dome has been in approximately steady-state for about the last 8 ooo years, but that, prior to that time, large changes had taken place.

For the r 969 Cape Folger hole, a large isotope transition occurred at the $240 \mathrm{~m}$ depth, where the ice thickness was $364 \mathrm{~m}$. This transition zone also corresponded to large changes in many other ice-core properties, e.g. chemical content, crystallography, and bubble elongation. 


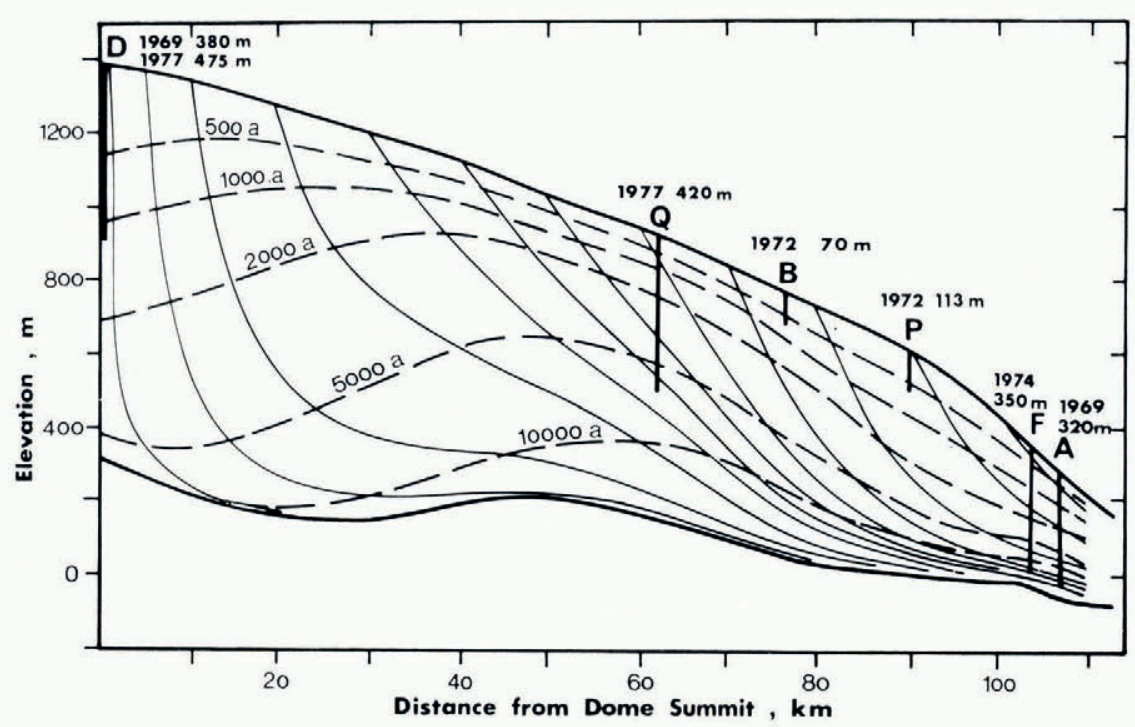

Fig. I. A section through Law Dome from the summit to Cape Folger is shown with the locations and depths of bore holes and cores obtained to date. Examples of modelled particle paths and ages, derived from the present accumulation and velocities with a simple flow regime, are also shown.

The crystallography of this core has been studied in detail, much of the work having been carried out by G. Wakahama and M. Matsuda (of the Institute of Low Temperature Science at Hokkaido University) in connection with their visits to Melbourne. A summary of part of the results of this work has been reported by Budd (1972) and Matsuda and others (1976).

The main features of the spatial distribution of the crystal structure are that:

(a) the upper ice responds to the surface stress and strain-rates;

(b) the middle portion develops a fabric which is associated with the down-slope (almost horizontal) shear of the ice and which has a single-maximum crystal orientation which is predominantly near to the vertical; and

(c) the basal layer consists of very large crystals with multiple maximum c-axis concentrations and a structure which is apparently twin-like (cf. Matsuda and others, 1976).

Experimental work had established that the single-maximum ice, when sheared in the plane perpendicular to the maximum, deformed several times more readily than randomlyoriented ice (Lile, 1978).

This posed a dilemma, since the flow law used by Budd (r969) had given velocities comparable to the measured surface velocities without invoking effects of anisotropy.

\section{The i 974 Programme and subsequent developments}

In 1974, a hole was cored at a location designated SGF, about three kilometres up-stream from the previous hole at SGA. At SGF the ice-surface elevation was $360 \mathrm{~m}$ and the ice thickness, as determined by radio echo-sounding, $385 \mathrm{~m}$. In fact, two holes were drilled at this location about $100 \mathrm{~m}$ apart. The first hole to be drilled yielded the core which was subsequently subjected to detailed analysis in Melbourne. After the core had been extracted, however, certain necessary measurements on the hole could not be taken due to a blockage. A second core was therefore drilled in order to provide an unobstructed hole which was first 
measured for temperature, diameter, and inclination, then filled with fluid, to balance the hydrostatic pressure, and then re-instrumented. The fact that the ice cores from the SGA and SGF holes, several kilometres apart, showed close similarity, indicates that the minor separation of the analysed core from the instrumented hole is unimportant.

The SGA and SGF holes were on the survey line from Dome Summit to Cape Folger, which had been studied in detail during previous years and for which large-scale strain-rates had been measured. A new strain-grid, with markers spaced some roo $\mathrm{m}$ apart, was established around these holes in order to associate the local strain data so obtained with the largescale values.

The core obtained from SGF was almost continuous and was returned to Australia in 1975 for analysis. Shavings were taken from each length of core (about $1.8 \mathrm{~m}$ long) for meanisotope-ratio studies. The results of the measurements from these were presented by Budd and Morgan (1977).

During 1977, a further hole was cored at SGQ to a depth of $420 \mathrm{~m}$ and another coring was made at Dome Summit to $475 \mathrm{~m}$. These bore holes were instrumented and filled with fluid. In addition, the 1974 hole at SGF was re-surveyed for inclination and azimuth. The in-situ shear-rates of the ice have been derived from these measurements.

\section{LABoratory studies}

The main aim of the laboratory studies was to determine the flow properties of the ice from the core, simulating as far as was practicable the in-situ conditions in the ice sheet. A large number of deformation testing rigs were constructed for the study of ice-core deformation in simple shear. The experiments were conducted in simple shear because the average shear through the ice was large in comparison to the surface extension or compression. The ice cores had been oriented during the coring process. (A magnetic compass, fitted with a time-delay mechanism which locked the compass card in position indicated the magnetic azimuth of the drill. A scriber in the drill barrel made a grove along the length of the core to record the core-drill orientation.) Samples from the oriented core were sheared in the direction of the measured surface velocity. The shear stress in the ice, as determined from the depth below the surface and the surface slope (which is averaged over about ten ice thicknesses), ranged from $0-0.7$ bar octahedral shear (o.s., which is $(2 / 3)^{\frac{1}{2}}$ times the simple shear stress). The bore-hole temperatures ranged from $-10^{\circ} \mathrm{C}$ near the surface to $-2.5^{\circ} \mathrm{C}$ at $317 \mathrm{~m}$, the greatest depth at which measurements were obtained, and it would appear that pressure-melting point is reached at the base of the ice. The tests carried out in the laboratory so far range from -0.85 to $-20^{\circ} \mathrm{C}$ and from 0.2 to $\mathrm{I}$.o bar o.s. At deeper levels, the ice core contained distinctly elongated bubbles which were aligned generally in the direction of the measured surface flow direction. These bubbles were also used to align the core in the shear direction.

The shear apparatus consisted of two plates, $20 \mathrm{~mm}$ apart, constrained by bearings to move parallel to each other. Core samples were cut, $100 \mathrm{~mm}$ diameter by $25 \mathrm{~mm}$ thick, and frozen into recessed holes in the plates. A constant load was applied by the use either of weights or of a spring-balance system. Dial gauges and electronic transducer recording were used to monitor displacement. The rigs were placed inside constant-temperature kerosene baths in deep freezers. Sets of four or five rigs were operated in the same stirred bath, the temperature of which could be readily controlled to $\approx 0.1^{\circ} \mathrm{C}$.

In order to compare the core ice with other types of ice, a complete set of measurements was also made on similar specimens of laboratory-made polycrystalline ice of comparable crystal size $(\approx 5 \mathrm{~mm})$; this artificial ice was statistically isotropic and had a random orientation. Earlier creep studies on ice of different crystal sizes $\left(0.5^{-1} 5 \mathrm{~mm}\right)$ indicated that crystal size alone was not a major factor influencing the strain-rate. 
A detailed study of the physical properties of the core was made at distances of not more than $20 \mathrm{~m}$ along the length of the core. Properties studied to date include: crystal size, crystal orientation fabrics, and the size, shape, and elongation of bubbles. The bubble distribution in the ice core was apparently responsible for a banded appearance which increased with depth. It also seems that this banded appearance was made more extensive by cracking caused by the drilling process. Experiments on adjacent fine-banded and unbanded sections of the core did not, however, reveal a significant difference in shear-rates.

\section{THE FLOW LAW FOR ISOTROPIC IGE}

The main problem with ice-deformation tests involving stresses in the range $0 . \mathrm{I}-\mathrm{I}$ bar is that a long time is required for steady-state to be reached. This problem is more severe at lower temperatures. It has been shown that about one per cent strain is required to reach minimum strain-rate, and this will take a very long time at a low stress. Steinemann (1954) found that recrystallization of ice samples occurred following the onset of tertiary creep after a few per cent strain. It appears that the minimum creep-rates for initially randomly oriented ice occurs at about one per cent strain for a wide range of strain-rates. Thus, with the present experiments, a clear minimum was sought, or else the experiments were continued as long as possible towards a strain of one per cent. Consequently, the minimum strain-rates obtained for the low stresses here are from much longer times than those generally reported by other workers (e.g. Duval, r973). The use of the minimum strain-rate in this context allows the time parameter to be removed from the flow law, and, at one per cent strain, significant recrystallization has not yet occurred, so that the sample crystallography can be considered to be the same as that of the initial sample. Beyond the minimum strain-rate, higher tertiary strain-rates develop, as does recrystallization which changes the initial fabric.

The average strain-rate through the ice at SGF is about $0.025 \mathrm{a}^{-\mathrm{I}}$. For the upper ice, where the stresses are low, much lower strain-rates occur. Consequently, it has been found that the creep tests needed to be continued in some cases, for up to two years in order to reach a clear minimum. It has not been found practicable to pre-stress the ice to near one per cent at a higher stress and then to apply lower stresses, because the ice takes a long time to recover from the higher stress, as shown by Mellor and Testa (1969).

A more practical method has been to carry out tests at higher temperatures to near one per cent strain and then to decrease the temperature, in order to obtain a steady-state more quickly at a lower temperature. Even then, with 0.22 bar at $-2{ }^{\circ} \mathrm{C}$, some six months is needed to reach steady-state, and, after lowering the temperature, some further months are required to obtain a new steady-state.

The Andrade law, as examined by Glen (1955), and others, has not been found to estimate the final steady-state satisfactorily, since its estimate changes with the duration of the test. Its application is therefore unsuitable in this context.

Results from the measured minimum strain-rates obtained so far are illustrated in Figure 2. It is apparent from these results that, when the minimum strain-rates are obtained, the strain-rates for the lower stresses continue to decrease with decreasing stress as a power law with exponent of about $n=3$. The tendency towards linearity at lower stresses for other published laboratory tests seems to be a result of their not having reached the minimum strain-rate. For other reported field data, the higher strain-rates at lower stresses could be due to ice-crystal anisotropy, as discussed below. In general, the results here are compatible with the extrapolation of minimum strain-rates at low stresses from the minimum strain-rates of higher stress compression tests obtained by other workers (e.g. Budd (1969) and Barnes and others (I97I)). For some of the lower strain-rates, however, estimation of the minimum strain-rate was still necessary. In these cases where the minimum strain-rates were not quite reached, it was estimated by extrapolating the curve through the experimental points on a 
plot of $\log$ strain-rate against log strain to one per cent strain. For experiments in which the temperature was varied at constant stress, the estimate was obtained from a log strain-rate against log time plot (e.g. as shown in Figure 3). The asymptote to the experimental curve was taken as the estimate of the minimum strain-rate. The estimated error in the extrapolation is included in the error bars shown in Figure 2, increasing with decreasing strain-rate. Recent compression tests by R. Lile and T. H. Jacka give results which are compatible with the data of Figure 2 and thereby give further support to the idea that octahedral shear stress gives a correct comparison between compression and shear tests (Lile, unpublished).

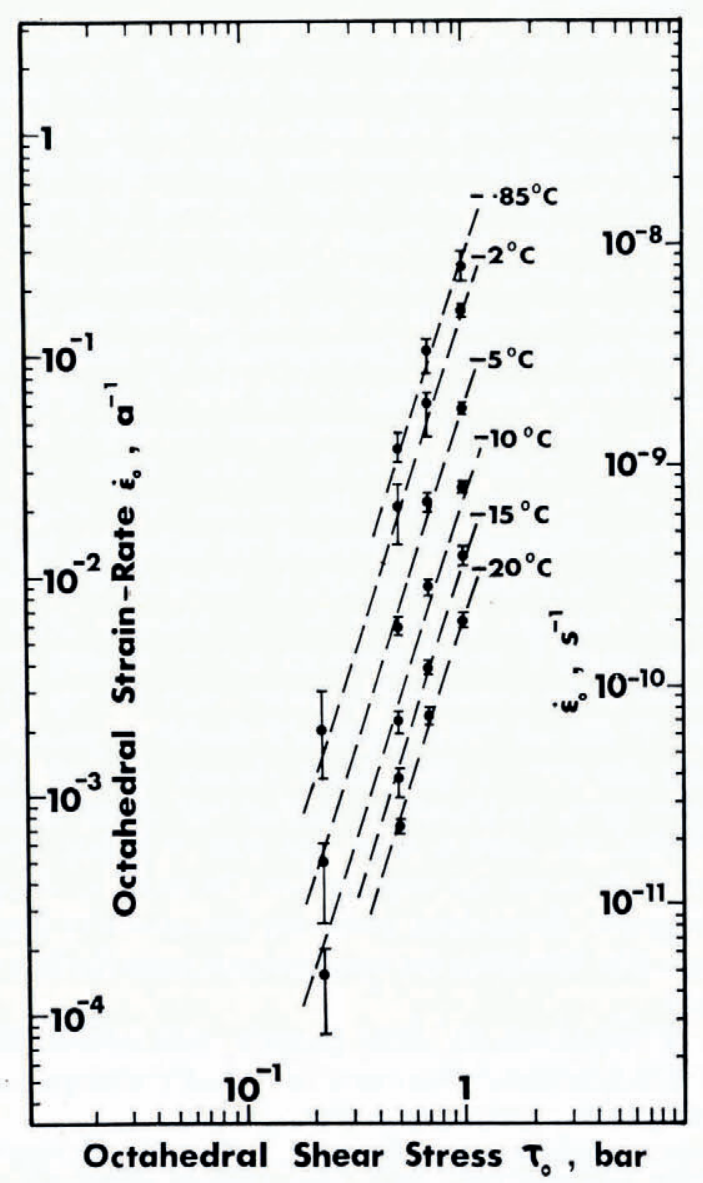

Fig. 2. The flow law for the isotropic laboratory-made polycrystalline ice is shown as derived from minimum creep-rates at temperatures from $-0.85^{\circ} \mathrm{C}$ to $-20^{\circ} \mathrm{C}$. The vertical lines on the points represent estimated error bars.

\section{The flow LAW For anisotropic ice}

A large number of long-term tests have also been carried out for core ice to cover the same range of stress and temperature. Samples from a number of depths have been studied. For most runs (of four or five samples tested at the same stress and temperature) a sample of the artificial isotropic ice was also included. Once again the long time required to reach a minimum creep-rate was a problem. A typical example of curves of strain-rate versus time plotted logarithmically for a set of three samples is shown in Figure 3. The different strain- 
rates of the samples from different depths demonstrate the effect of anisotropy, illustrated in Figure 4 , which shows the orientation fabrics of the major zones through the ice. In all cases the lowest strain-rates were obtained for the isotropic ice. The highest strain-rates were obtained for the ice in about the third quartile of the depth from the surface, where a strong near-vertical maximum occurs in the orientation fabrics. For each sample at a given stress and temperature, the strain-rate relative to that of the isotropic ice has been calculated, and is called the enhancement factor $f$. The enhancement factor as a function of depth for the results of Figure 3 is shown in Figure 5. The enhancement factor for each ice sample is being studied for a range of temperatures and stresses.

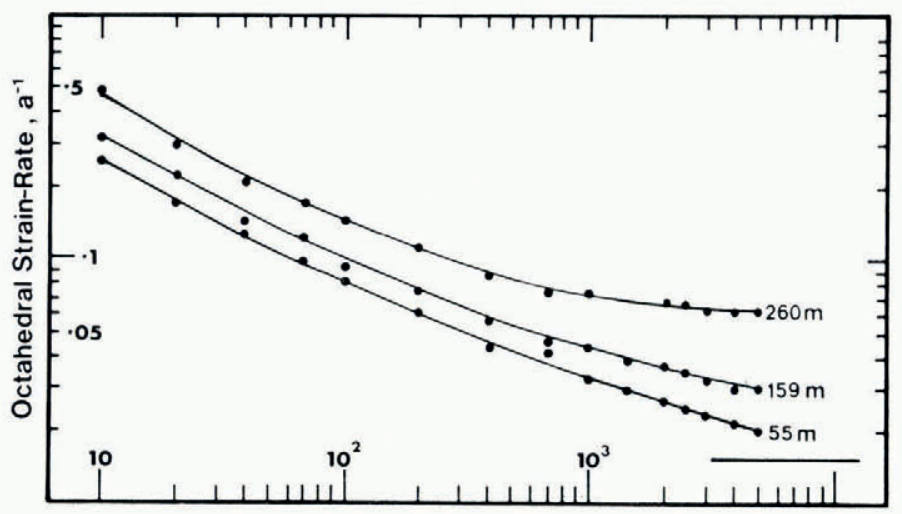

Time, $\mathrm{h}$

Fig. 3. Results of some creep experiments for shear on ice core for 0.5 bar at $-2{ }^{\circ} \mathrm{C}$, showing the long times required for minimum or steady-state strain-rates. The depths at which the cores were obtained are shown. The solid horizontal line represents the corresponding value obtained for isotropic ice.

The dependence of the flow-rate on the orientation fabric of polycrystalline ice for an arbitrary stress situation has been treated in a general way by Lile (1978). Space does not allow a detailed analysis of this complex topic here, but, as an indication of the first-order effect of the enhancement factor on the fabric for simple shear, we can use an approximate measure of fabric strength. For example, if the median inclination $\phi\left(\frac{1}{2}\right)$ of the $c$-axes in the sample to the shear-plane normal is calculated (i.e. the inclination for which half of the $c$-axes are near to, and half far from, the normal), then the $f$ value can be expressed as a function of $\phi\left(\frac{1}{2}\right)$. A similar result applies to the first quartile about the normal $\phi\left(\frac{1}{4}\right)$ which shows less scatter (Fig. 5). This allows the results obtained here to be applied to other situations and, perhaps, also to be associated directly with other bulk properties, e.g. sonic velocities, as studied by Bentley (1972).

This median angle, while it is appropriate, can only be an approximate measure because the reaction of different crystals is not circularly symmetric about the normal to the shear plane. In fact, for a single crystal, the shear-rate on its basal plane is affected much more by increasing the angle of the $c$-axis from the vertical in the plane of flow than by increasing the angle of the $c$-axis from the vertical in a plane at right-angles to the plane of flow. This variable dependence can be taken into account by appropriate weighting for a longitude angle $\theta$. A more detailed discussion of this general topic is given by Lile (1978, unpublished).

\section{FABRic SYSTEMS IN ICE SHEETS}

The pattern of the variation in the crystal-orientation fabrics for Law Dome, as depicted in Figures I and 4, seems to be typical of cold ice sheets in general. Similar fabric patterns have been obtained at the following locations: Byrd (Gow and Williamson, 1976), Terre 
Adélie (Lorius and Vallon, I967), Barnes Ice Cap (Hooke, I973), Vostok (Barkov, I973), and Meserve Glacier (Anderton, i974).

In all of these, there is a tendency to develop a zone, generally in the middle third of the ice thickness, of strong, near-vertical, single-maximum concentration in the $c$-axes. From the results obtained here, it can be expected that the flow-rate of this ice would be about four times higher than for isotropic ice at the same stress and temperature. This is borne out by a
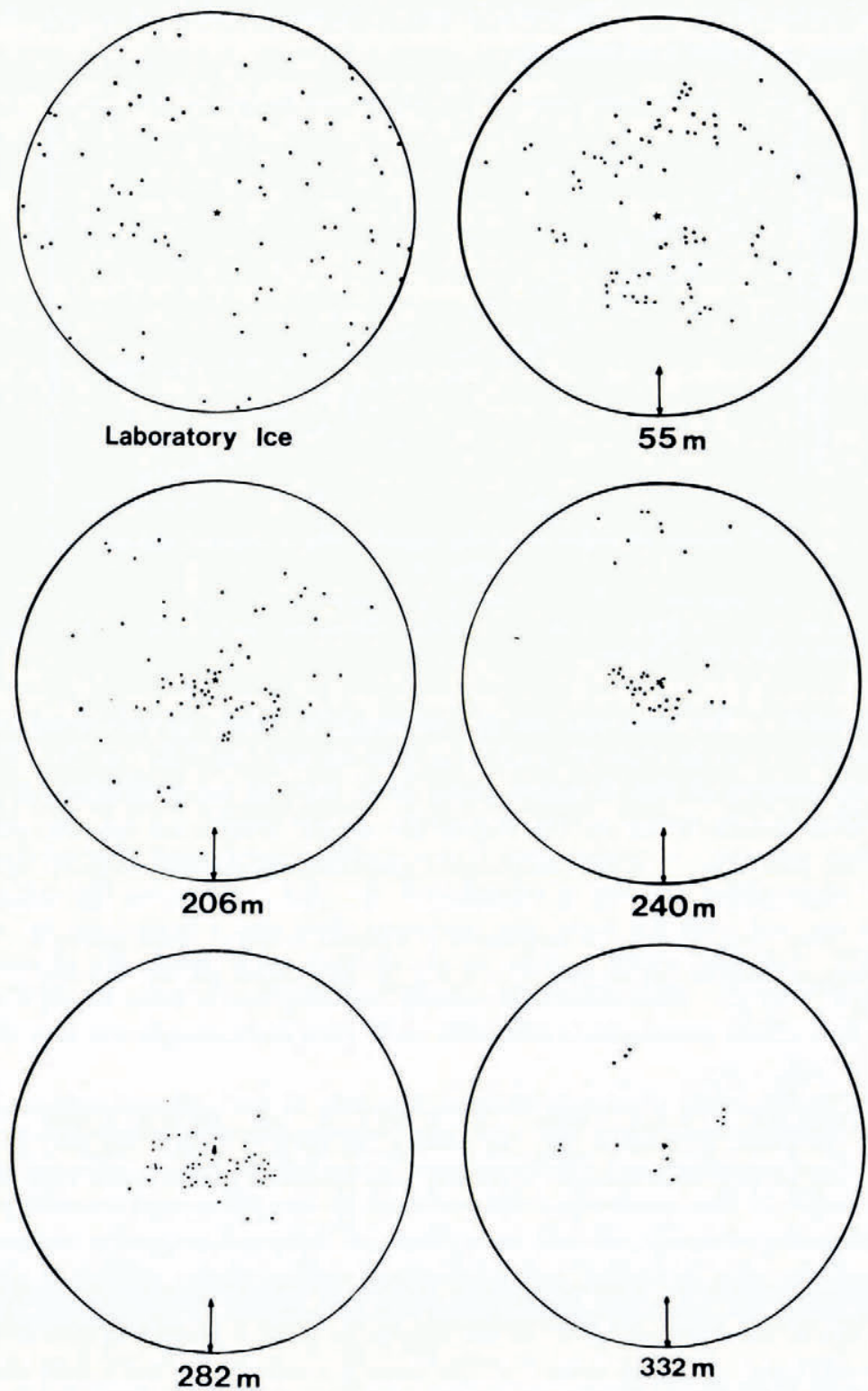

Fig. 4. The general distribution of crystal c-axis orientation fabrics (lower-hemisphere plot) for horizontal sections through the ice core are shown with the depths indicated, together with the fabric for laboratory-made isotropic ice. The fabrics depict the transition from vertical compression with longitudinal extension at the surface, to increasing horizontal shear, then to the large-crystal ice with multiple maxima at the base. The arrow indicates the general direction of flow. 

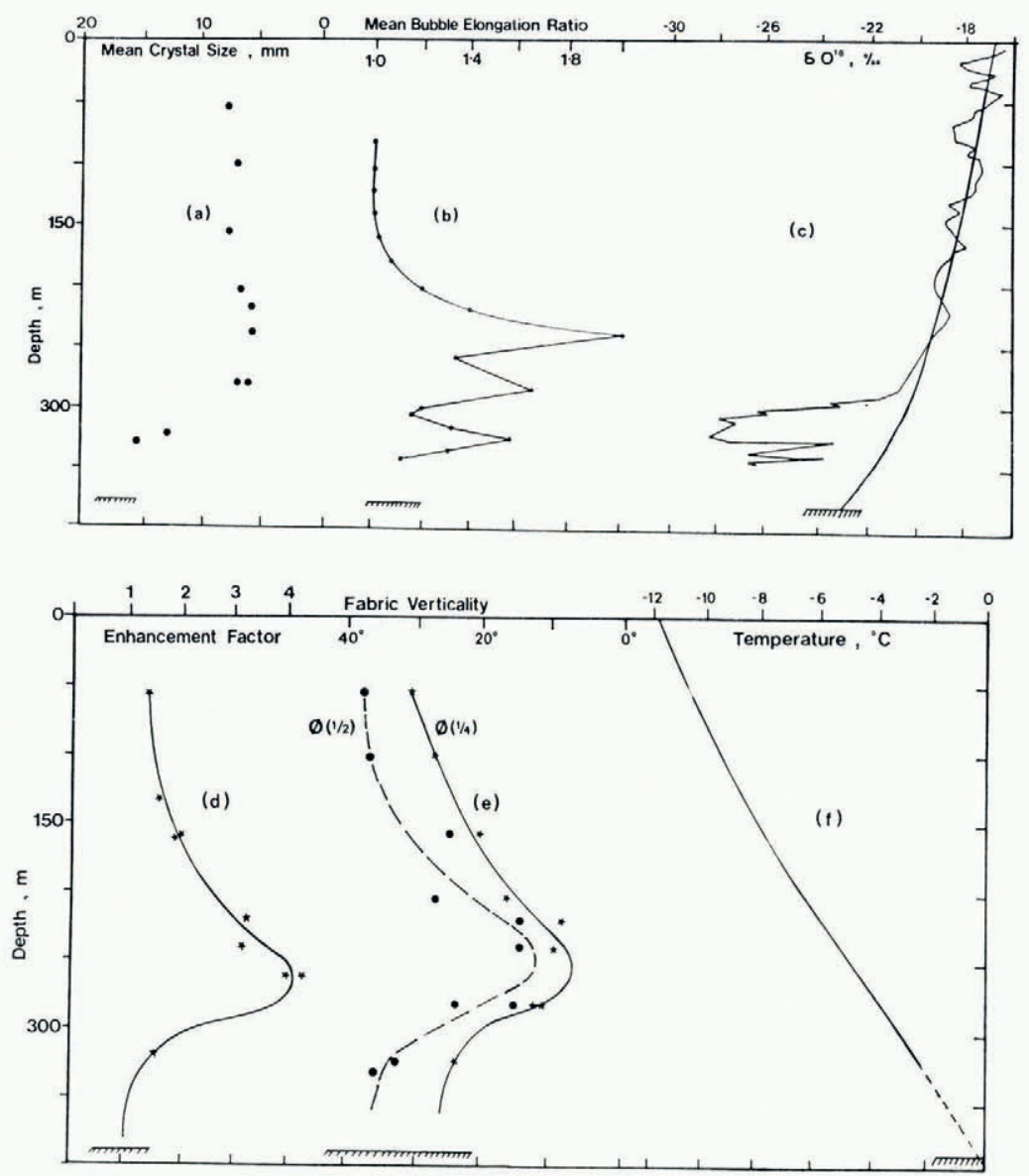

Fig. 5. Various properties of the ice sheet at SGF are shown as a function of depth:

(a) mean crystal size in the core;

(b) mean bubble elongation;

(c) relative oxygen-isotope concentrations, from Budd and Morgan (1977);

(d) enhancement factor from shear experiments;

(e) fabric strength measured as median $\phi\left(\frac{1}{2}\right)$, and first quartile $\phi\left(\frac{1}{4}\right)$, verticality;

$(f)$ bore-hole temperature profile (solid line) with extrapolation to pressure melting at the base (dashed line).

comparison of the isotropic ice flow-rates shown in Figure 2 with the deepest shear-rates measured at Byrd by Garfield and Ueda (1976), when the effects of the longitudinal strainrates at Byrd are also taken into account. The use of an enhancement factor as given here allows the flow-rates through an ice mass to be calculated if the crystal structure of the ice is known. The general pattern of the spatial crystallographic distribution seems to be uniform to the extent that it could be estimated for a given location, or, perhaps, measured on a large scale by seismic means (Bentley, I971, 1975). Most of the fabric studies mentioned above indicate a general tendency for the basal layer of ice to consist of large-crystal ice without the single-maximum fabric. The results obtained in the deformation tests and the bore-hole results described below suggest that this type of ice shears much less readily than the ice above it. It would therefore appear that there may be a widespread, rather immobile (or stagnant) layer at the base of the ice sheet. The relatively echo-free basal zone noted in radio 


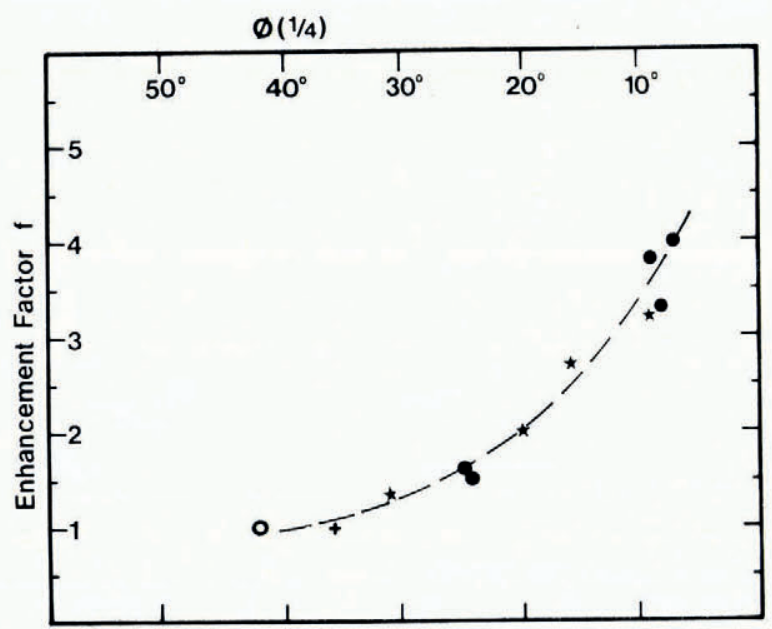

Fig. 6. The enhancement factor obtained for the ice-core strain-rates in horizontal shear relative to that of the randomly oriented ice is shown as a function of the first quartile of verticality as measured from the orientation fabrics. For isotropic ice the first quartile would be $41.4^{\circ}$. Actual values between $43^{\circ}$ and $36^{\circ}$ were obtained for the laboratory ice $(\bigcirc$ and +$)$. The dots are for measurements on the same sample whereas the stars are for interpolated neighbouring values.

echo-sounding records by Robin and others (1977) may bear some relation to this layer. It may be that the relatively immobile layer tends to be trapped in the bed irregularities, and, as a result, tends to smooth out the flow of the upper layers. This feature certainly deserves further field investigation. For Law Dome, this basal layer also corresponds to the ice of much older origin as determined by isotope studies. The ages and origins of the ice in the basal layers of ice sheets (e.g. Camp Century) cannot be accurately determined without an adequate understanding of the flow regime in the basal layer.

\section{OTHER ICE GORE PROPERTIES}

In Figure 5 a number of physical properties of the ice core are depicted on the same depth scale, viz. crystal size, central fabric strength, bubble elongation, isotope ratios, and in-situ temperature.

All of these properties seem to fit the general picture described above. Russell-Head (unpublished) has documented these observations more fully; a few general comments are made here.

Since the bubble sizes and shapes in a given sample were quite variable, the distributions of sizes and elongations were measured. The mean bubble elongations appear to have a strong association with either the shear-rates or the total strain. This suggests that the bubble configurations in relation to the ice flow are worth further study.

There is a marked transition in a number of the properties near the depth of $280 \mathrm{~m}$. A similar transition occurred in the SGA core at about $240 \mathrm{~m}$ depth, where the ice thickness was $364 \mathrm{~m}$. This suggests that the features observed here are representative of a large-scale pattern.

The temperature profile in the lower layer shows a slightly reversed curvature, which can be explained by the observed deformation profile with high shear in the layer with a single vertical maximum fabric. 


\section{Comparison of Bore-hole Shear With laboratory Results}

During 1974 the SGF bore hole was logged for inclination and re-surveyed two months later. The repeatability of the measurements gives an indication of the accuracy of the bore-hole-surveying system, but the time difference and deformation-rates were too small to give significant shear results.

Two further surveys were made during 1977 by Mr J. Wilson and colleagues of the 1977 ANARE (Australian National Antarctic Research Expeditions). The last survey was made 3.0 years after the initial survey of 1974 . Using the measurements obtained on these surveys, significant three-dimensional inclination changes have been determined down to the depth of $\approx 280 \mathrm{~m}$. Below that depth, bore-hole closure, which occurred largely before the fluid filling, prevented deeper penetration. Nevertheless, since the surface velocity is well known, the remaining shear in the basal layer can be deduced if basal sliding is assumed to be negligible.

The velocity profile in the ice is obtained by using the measured surface velocity and integrating the measured bore-hole shear-rates from the surface downwards to the lowest depth for which they were obtained. The resultant profile is shown in Figure $7 \mathrm{~b}$. It is clear that the total shear deformation in the lower unmeasured section must be small. The heavy dashed line represents the use of an extrapolated smooth strain-rate as shown in Figure 7 a, whereas the straight dashed line represents an average strain-rate.

If the results of the laboratory measurements (shown in Figs 5 and 7 a) were used to calculate the shear-rates of either the large-crystal ice or the randomly-oriented laboratory ice for the temperature and assumed shear stress in the basal layer, the rates would be very much higher than those indicated by the bore-hole measurements.

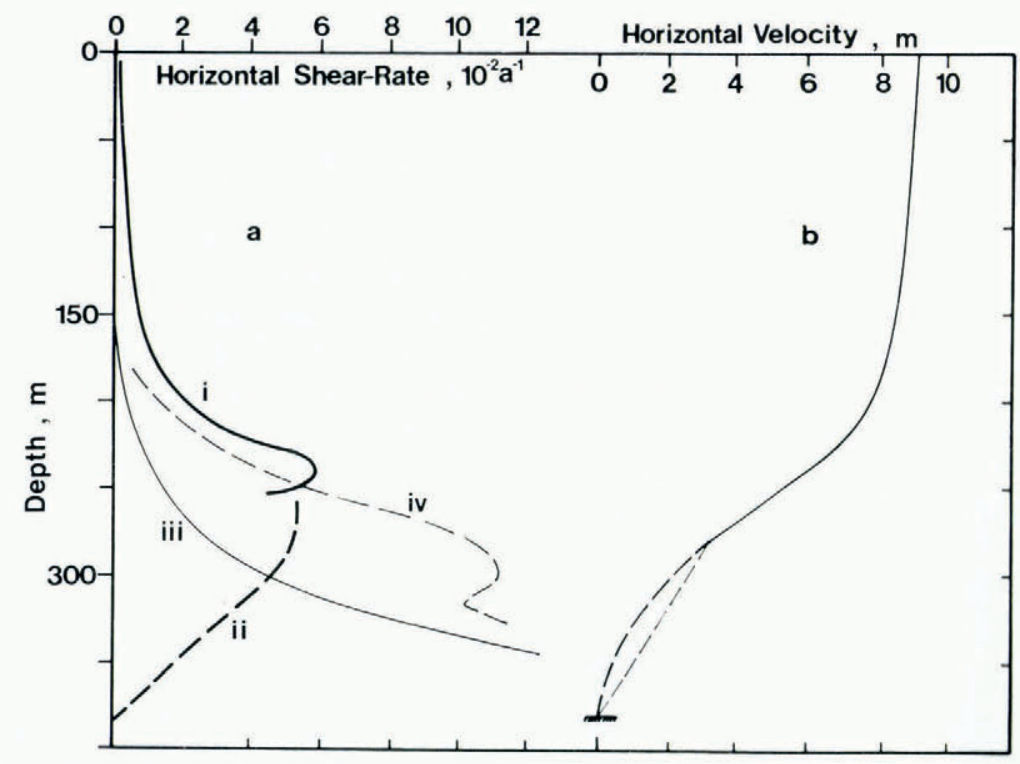

Fig. 7.

a Horizontal shear-rate as a function of depth:

(i) measured shear in bore hole;

(ii) extrapolation to the bed;

(iii) shear-rates for isotropic ice;

(iv) shear-rates for core ice.

$b$ Horizontal velocity profile with depth: full line-as measured in bore hole; dashed lines - possible extrapolations with depth. 
Relaxation of the ice after coring is not thought to have altered the rheology of the ice-core samples because the match of the laboratory-core deformation-rates and the measured borehole shear-rates is reasonably close down to about $240 \mathrm{~m}$ depth. Below that level the required decrease in strain-rate is too large to be explained simply by a change in the ice-core rheology alone.

It is therefore concluded that the shear stress must decrease towards the bed after reaching a maximum in the region of the high-shear layer located at the depth of about two-thirds of the ice thickness.

This conclusion is in agreement with the comment made by Harrison on the paper by Budd and others (1976) and also referred to by Kamb (1970), that is, for flow over small undulations of wavelength $\lambda$, the maximum shear occurs at a height $h=\lambda / 2 \pi$ above the mean base. Echo-sounding in the region of the bore hole and up-stream of it shows a mean wavelength for the predominant bedrock undulations of about $\mathrm{I} . \mathrm{I} \mathrm{km}$ which would give a value for $h$ of about $175 \mathrm{~m}$. This is in reasonable agreement with the height of about $155 \mathrm{~m}$ above the bed obtained for the high-shear zone here.

It therefore appears that the high concentration of vertical $c$-axes is a result of the high horizontal shear stress, while the large-crystal ice results from a type of annealing process associated with the lower shear stress and higher temperature towards the base.

\section{Io. Summary AND conclusions}

Measurements of steady-state creep for stresses below one bar are difficult to obtain because long times are required. For laboratory-made isotropic ice, strains of about one per cent were found necessary to establish a minimum strain-rate. A flow law based on these minimum rates has been determined for the range 0.2 to I bar octahedral shear stress and from -0.85 to $-20^{\circ} \mathrm{C}$, with simple shear apparatus.

Ice core from the surface to the bed of Law Dome shows a systematic change, from crystal fabrics associated with surface stress, to near-vertical single-maximum fabrics associated with down-slope shear in the lower part, and then to ice with a large-crystal multiple-maximum fabric at the base.

The flow properties of this core ice, subjected to simple shear in the in-situ configuration, have been determined within the same range as that for the isotropic ice. The flow-rates relative to those of the isotropic ice have been evaluated as a function of a simple measure of fabric strength normal to the shear plane. The enhancement factor thus determined indicates that the ice sheet shears about four times more readily in the region of the third quartile of depth than it would if it were composed of isotropic ice. In contrast, the ice from the basal zone was found to have flow-rates comparable with those of the isotropic ice.

The above results compare favourably with direct measurement of bore-hole shear, down to the depth of the high shear zone.

Below this depth there is very little residual shear strain. This result cannot be explained by the flow properties of the ice alone. It is concluded that the stress must decrease towards the base, and that this probably contributes to the development of the large-crystal structure.

This type of differential motion in the ice is compatible with the variation with depth of a number of other properties of the ice core, of which perhaps the most striking is that of bubble elongation.

The similarity in the general pattern of fabrics described here with those from other locations suggests that the inferred differential flow pattern with depth associated with the ice crystal structure may also be typical of cold ice sheets in general, where irregular bedrock causes a reduction of the shear stress in the basal layer. 


\section{REFERENCES}

Anderton, P. W. 1974. Ice fabrics and petrography, Meserve Glacier, Antarctica. Fournal of Glaciology, Vol. I3, No. 68 , p. $285-306$.

Barkov, N. I. 1973. Rezul'taty issledovaniya skvazhiny i ledyanogo kerna na stantsii Vostok v 1970-1972 gg. [Results of the investigation of the bore hole and ice core at Vostok Station in 1970-72]. Materialy Glyatsiologicheskikh Issledovaniy. Khronika. Obsuzhdeniya, Vyp. 22, p. 77-81.

Barnes, P., and others. 1971. Friction and creep of polycrystalline ice, by P. Barnes, D. Tabor, and J. C. F. Walker. Proceedings of the Royal Society of London, Ser. A, Vol. 324, No. 1557, p. 1 $27-55$.

Bentley, C. R. 1971. Seismic anisotropy in the West Antarctic ice sheet. (In Crary, A. P., ed. Antarctic snow and ice studies II. Washington, D.C., American Geophysical Union, p. 131-77. (Antarctic Research Series, Vol. I6.))

Bentley, C. R. 1972. Seismic-wave velocities in anisotropic ice: a comparison of measured and calculated values in and around the deep drill hole at Byrd Station, Antarctica. Fournal of Geophysical Research, Vol. 77, No. 23, p. $4406-20$.

Bentley, C. R. 1975. Advances in geophysical exploration of ice sheets and glaciers. Fournal of Glaciology, Vol. I 5 , No. 73 , p. $113-35$.

Budd, W. F. 1968. The longitudinal velocity profile of large ice masses. Union de Géodésie et Géophysique Internationale. Association Internationale d'Hydrologie Scientifique. Assemblée générale de Berne, 25 sept.-7 oct. I967. [Commission de Neiges et Glaces.] Rapports et discussions, p. 58-77. (Publication No. 79 de l'Association Internationale d'Hydrologie Scientifique.)

Budd, W. F. I 969 . The dynamics of ice masses. ANARE Scientific Reports. Ser. A(IV). Glaciology. Publication No. 108.

Budd, W. F. [1970.] The Wilkes ice cap project. [Union Géodésique et Géophysique Internationale. Association Internationale d'Hydrologie Scientifique.] [International Council of Scientific Unions. Scientific Committee on Antarctic Research. International Association of Scientific Hydrology. Commission of Snow and Ice.] International Symposium on Antarctic Glaciological Exploration (ISAGE), Hanover, New Hampshire, U.S.A., 3-7 September 1968, p. 414-29. [(Publication No. 86 [de l'Association Internationale d'Hydrologie Scientifique].)]

Budd, W. F. 1972. The development of crystal orientation fabrics in moving ice. Zeitschrift für Gletscherkunde und Glazialgeologie, Bd. 8, Ht. I-2, p. 65-105.

Budd, W. F., and Matsuda, M. I974. Nijiku-kuriipu asshuku ni okeru takesshōhyō no sentaku-hōisei ni tsuite [On preferred orientation of polycrystalline ice by biaxial creep]. Teion-kagaku: Low Temperature Science, Ser. A, [No.] 32, p. $261-65$.

Budd, W. F., and Morgan, V. I. I977. Isotopes, climate and ice sheet dynamics from core studies on Law Dome, Antarctica. [Union Géodésique et Géophysique Internationale. Association Internationale des Sciences Hydrologiques. Commission des Neiges et Glaces.] Symposium. Isotopes et impuretés dans les neiges et glaces. Actes du colloque de Grenoble, août/septembre 1975, p. 312-21. (IAHS-AISH Publication No. 1 I 8.)

Budd, W. F., and others. 1976. Measured and computed temperature distributions in the Law Dome ice cap, Antarctica, by W. F. Budd, N. W. Young, and C. R. Austin. Journal of Glaciology, Vol. 16, No. 74, p. 99-1 10.

Duval, P. I973. Fluage de la glace polycristalline pour les faibles contraintes. Comptes Rendus Hebdomadaires des Séances de l'Académie des Sciences (Paris), Sér. A, Tom. 277, No. 14, p. 703-o6.

Garfield, D. E., and Ueda, H. T. 1976. Resurvey of the "Byrd" Station, Antarctica, drill hole. Fournal of Glaciology, Vol. I 7, No. 75, p. 29-34.

Glen, J. W. 1955. The creep of polycrystalline ice. Proceedings of the Royal Society of London, Ser. A, Vol. 228, No. 1175 , p. 5 19-38.

Gow, A. J., and Williamson, T. C. 1976. Rheological implications of the internal structure and crystal fabrics of the West Antarctic ice sheet as revealed by deep core drilling at Byrd Station. Geological Society of America. Bulletin, Vol. 87, No. 12, p. 1665-77.

Hooke, R. L. I973. Structure and flow in the margin of the Barnes Ice Cap, Baffin Island, N.W.T., Canada. Journal of Glaciology, Vol. 12, No. 66, p. 423-38.

Kamb, W. B. 1970. Sliding motion of glaciers: theory and observation. Reviews of Geophysics and Space Physics, Vol. 8, No. 4, p. $673-728$

Lile, R. C. 1978 . The effect of anisotropy on the creep of polycrystalline ice. Journal of Glaciology, Vol. 21, No. 85, p. $475-83$.

Lile, R. C. Unpublished. The rheology of polycrystalline ice. [Ph.D. thesis, University of Melbourne, 1978.]

Lorius, C., and Vallon, M. I967. Étude structurographique d'un glacier antarctique. Comptes Rendus Hebdomadaires des Séances de l'Académie des Sciences (Paris), Sér. D, Tom. 265, No. 4, p. 315-18.

McLaren, W. A. I 968 . A study of the local ice cap near Wilkes, Antarctica. ANARE Scientific Reports. Ser. A(IV). Glaciology. Publication No. 103.

Matsuda, M., and others. I 976 . Nankyoku hyōshō-hyō no sōshō. Hyō-kesshō a-jiku no sokutei ni motozuku diayamondopatān no keisei ni tsuite [Twinning of ice from Antarctic ice sheet. Observations of $a$-axis orientation associated with diamond $c$-axis orientation fabric]. [By] M. Matsuda, G. Wakahama, W. F. Budd. Teion-kagaku: Low Temperature Science, Ser. A, [No.] 34, p. 163-71.

Mellor, M., and Testa, R. 1969. Creep of ice under low stress. Fournal of Glaciology, Vol. 8, No. 52, p. I47-52.

Robin, G. de Q., and others. I 977 . International studies of ice sheet and bedrock, by G. de Q. Robin, D. J. Drewry, and D. T. Meldrum. Philosophical Transactions of the Royal Society of London, Ser. B, Vol. 279, No. 963,
p. $185-96$.

Russell-Head, D. S. Unpublished. Ice sheet flow from borehole and laboratory studies. [M.Sc. thesis, University of Melbourne, i979.] 
Steinemann, S. [1956.] Flow and recrystallization of ice. Union Géodésique et Géophysique Internationale. Association Internationale d'Hydrologie Scientifique. Assemblée générale de Rome 1954. Tom. 4, p. 449-62. (Publication No. 39 de l'Association Internationale d'Hydrologie.)

\section{DISGUSSION}

R. W. BAKer: Did you perform any mechanical tests on ice with similar crystal fabrics, for instance random or single-pole fabrics, and did you vary the crystal size? If so, did you find any creep-rate dependence on grain size?

W. F. BudD: Deformation studies have been made on ice of a wide range of crystal sizes for randomly-oriented polycrystalline ice. The results show only small differences for minimum strain-rates (within $20 \%$ for sizes from I to Io $\mathrm{mm}$ ) but the ice with larger crystals tended to reach minimum sooner and developed tertiary flow-rates more quickly, giving higher strainrates than the small-crystal ice for the same time, but comparable rates for the same percentage strain. 